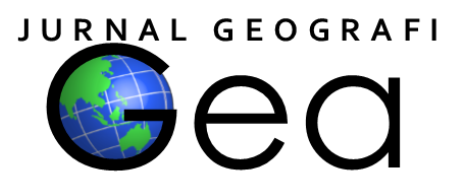

\title{
THE METHOD OF IMAGINARY MAP FOR HIGHER GEOGRAPHY LITERACY IN GENDER PERSPECTIVE
}

\author{
Isma Yullia Rahma ${ }^{1}$, Ahmad Yani ${ }^{2}$, Bagja Waluya ${ }^{3}$, Riki Ridwana ${ }^{4}$ \\ ${ }^{1,2,3,4}$ Department of Geography Education, Faculty of Social Science Education, \\ Universitas Pendidikan Indonesia \\ ${ }^{1}$ isma.yullia.rahma@upi.edu, ${ }^{2}$ ahmadyani@upi.edu, ${ }^{3}$ bagjawaluya@upi.edu, \\ ${ }^{4}$ rikiridwana@upi.edu
}

\begin{abstract}
The objectives of this study were (1) to compare the differences in perceptual tendencies between male and female students, (2) to analyze the opportunities for the effectiveness of the application of the imaginary map method in the classroom from a gender perspective. The total population of this study was 46 students of Geography Education, Universitas Pendidikan Indonesia, with a gender ratio of 50:50. Data were obtained by using literature study and questionnaire methods, and data analysis used was quantitative and qualitative. From the research, data are acquired that there is a general tendency for the same perception between genders, but the difference is that female has a wider and different level of object perception. Although there was a majority of answers to object perception, about $40 \%$ of students have a completely different perception of an object. Therefore, to be applied to the classroom, the teacher can work around by providing an imaginary map with the shape of an object that has been given a bold line, so that the image given to students can be more purpose-driven kind of attention. Furthermore, it is necessary to examine the method of the imaginary map directly to students who currently studying map material in class, as well as the need to develop imaginary objects for maps of all countries.
\end{abstract}

Keywords: geography literacy, perspective, gender, imaginary

\begin{abstract}
ABSTRAK
Tujuan dari penelitian ini adalah (1) membandingkan perbedaan kecenderungan persepsi antara laki-laki dan perempuan, (2) maleganalisis peluang efektivitas penerapan metode imajinasi peta di kelas dalam perspektif gender. Total populasi penelitian ini adalah 46 orang mahasiswa Pendidikan Geografi, Universitas Pendidikan Indonesia, dengan perbandingan gender 50:50. Perolehan data ditempuh dengan metode studi pustaka dan angket, serta analisis data yang digunakan adalah kuantitatif dan kualitatif. Dari penelitian diperoleh data bahwa secara umum, terdapat kecenderungan persepsi yang sama antar gender, namun bedanya perempuan memiliki tingkat persepsi objek yang lebih luas dan berbeda. Meski terdapat pilihan mayoritas jawaban persepsi objek, sekitar $40 \%$ peserta didik memiliki imajinasi yang berbeda sama sekali. Maka dari itu untuk dapat diterapkan pada kelas, guru bisa maleyiasatinya dengan memberikan imajinasi peta dengan bentuk objek yang telah diberi garis tegas, sehingga imajinasi yang diberikan pada peserta didik bisa lebih terarah. Lebih lanjut lagi perlunya uji coba
\end{abstract}


metode peta imajinasi secara langsung terhadap peserta didik yang sedang mempelajari materi peta di kelas, serta diperlukannya pengembangan objek imajinasi untuk peta seluruh negara.

Kata kunci: literasi geografi, perspektif, gender, imajinasi

\section{INTRODUCTION}

Knowledge of the locations and names of countries around the world is a very basic cognitive ability. However, this spatial intelligence often gets less attention. In classroom learning, teachers often convey spatial information using the lecture method, which leads to the results in weak imagination and comprehension of students. It is following McLeish (1968) that the use of classical methods can only be absorbed in a maximum of $40 \%$. As a result, a common mistake in recognizing the name of a country/location can be a fatal mistake.

Intelligence is defined as a general mental ability to learn and apply knowledge in manipulating the environment, as well as the ability to think abstractly (Ginting, 2003). Sonawat and Gogri (in Yaumi and Ibrahim, 2013: 15) define spatial intelligence as the ability to perceive the spatial world accurately and transform this spatial perception into various forms. According to Gardner (in Campbell, 2004: 22), visual-spatial intelligence is the ability to capture the visual-spatial world accurately. Meanwhile, Prabowo (in Wahono, 2014: 159) states that problems in the field related to basic learning, such as learning geometry in schools are caused by the relatively high level of abstractness of geometric objects and the lack of ability to visualize objects in students' minds. Human spatial action is not instantaneous, but lasts a long time as a statement of a process or system (Pamungkas and Ismail: 2020)

The above shows that spatial intelligence needs to be improved to increase students' abilities. Not only in learning geometry, learning to remember the geographic location of the countries all around the world is often difficult for some students. Therefore, in learning it is necessary to reduce verbalism learning, namely explaining a term or situation without visualization so this will lead to visualization only by the cognitive capture of students personally.

Learning about the geographic location is one of the geographical literacy section. This term comes from "geographic literacy" which is often shortened to "geoliteracy". One of the other ism of geographic thinkers, equating geography literacy with the ability to find a place on a map, namely place location knowledge (PLK) because PLK is the foundation/root of geography studies (Torrens, 2001; Saarinen and MacCabe , 1995). And then Eve, Price, and Counts (1994) stated that geographic literacy is the ability of an individual to read maps, spatial knowledge of the location, further understanding of the culture of the community associated with culture in a region.

It can be concluded that the students' geographic literacy can be thought to learn the characteristics of a location or place so that they can have a correct basic understanding of the world, further to understand society, as well as for decision making.

Another problem occurs when humans are faced with an image or visual, so there will be many different perceptions, especially in the gender perspective between males and females. The function of perception is to recognize what objects are there and localize or determine where these objects are. Recognition function is important for human survival because it relates to the ability to determine the location of an object, especially spatial localization.

It is said that the function of perception is in the dimension of human inner consciousness, and those things 
could affect perception. However, this function cannot work without the presence of the object being perceived. The object that is perceived is in the dimension it is in its consciousness. Therefore, differences in perceptions will always be inevitable, especially differences in perceptions between males and females.

The existence of this research aims to put forward the author's idea to improve geographic literacy intelligence because currently, the level of student literacy intelligence regarding spatial geography is still low, for that it needs to be encouraged by learning media that activate the imagination of students.

The formulations of the problem in this study are; 1 . How are the differences between male students 'and female students' imaginations? 2. Is this method effective to be applied in learning for all genders?

The objectives of this study are; 1 . Comparing the differences in perceptual trends between male and female, 2 . Analyzing the opportunities for the effectiveness of the application of the imaginary map method in the classroom from a gender perspective.

\section{RESEARCH METHODS}

The data collection method is a literature study and questionnaire. According to Nazir (2015) literature study is an important step when a researcher had determines a research topic, the next step is to conduct a study related to theory, the research will collect as much information as possible from related sources, that can be obtained from books, journals, magazines, research results (theses and dissertations), and other relevant sources. A questionnaire is a data collection technique that is done by giving a set of questions or written statements to the respondent to answer. The data analysis techniques in this study are as follows:

1. The composition of the instrument consisted of 8 multiple choice questions (Figure 1).

2. Distribution of printed and online questionnaires.

3. Ensuring the number of respondents between genders is balanced

4. Recording data was based on gender and choice of answers.

5. The analysis process is based on the presentation and the trend of answer choices between the genders.

6. Conclude

The location of the research is at Universitas Pendidikan Indonesia Jl. Dr. Setiabudi No.229, Isola, Kec. Sukasari, Bandung City, to be precise at the Faculty of Social Science Education which is located at coordinates $6.860704^{\circ} \mathrm{S}$ and $107.592994^{0} \mathrm{E}$ on Thursday, February $6^{\text {th }}$, 2020. The research was done by distributing a printed questionnaire to the class 4A of 2018 generation of Geography Education students in room $35,6^{\text {th }}$ floor at 1 p.m. Then the authors distributed an online questionnaire to the 2017 and 2016 generation of Geography Education students to balance the number of respondents based on gender.

Out of the total population of Geography Education generation of 2016, 2017, and 2018, there is 23 male and 23 female were taken, dominated by the younger generation.

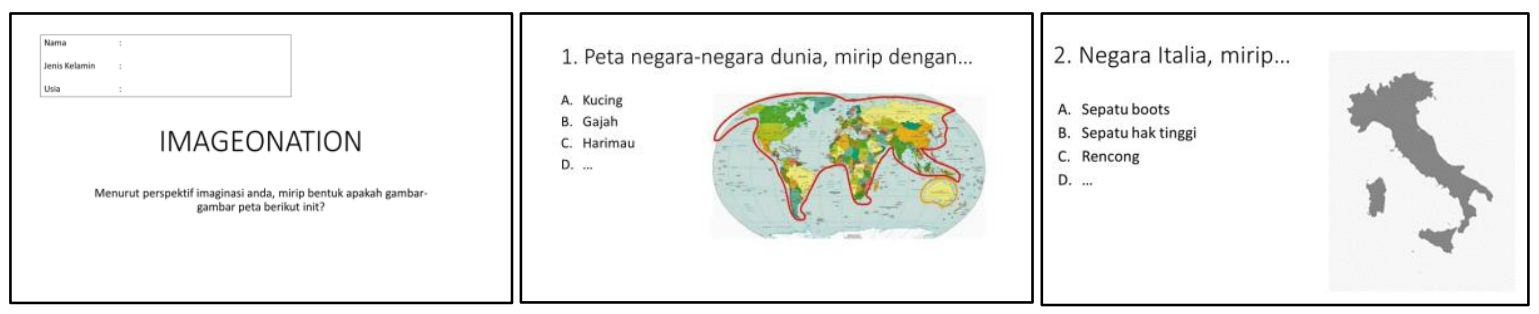



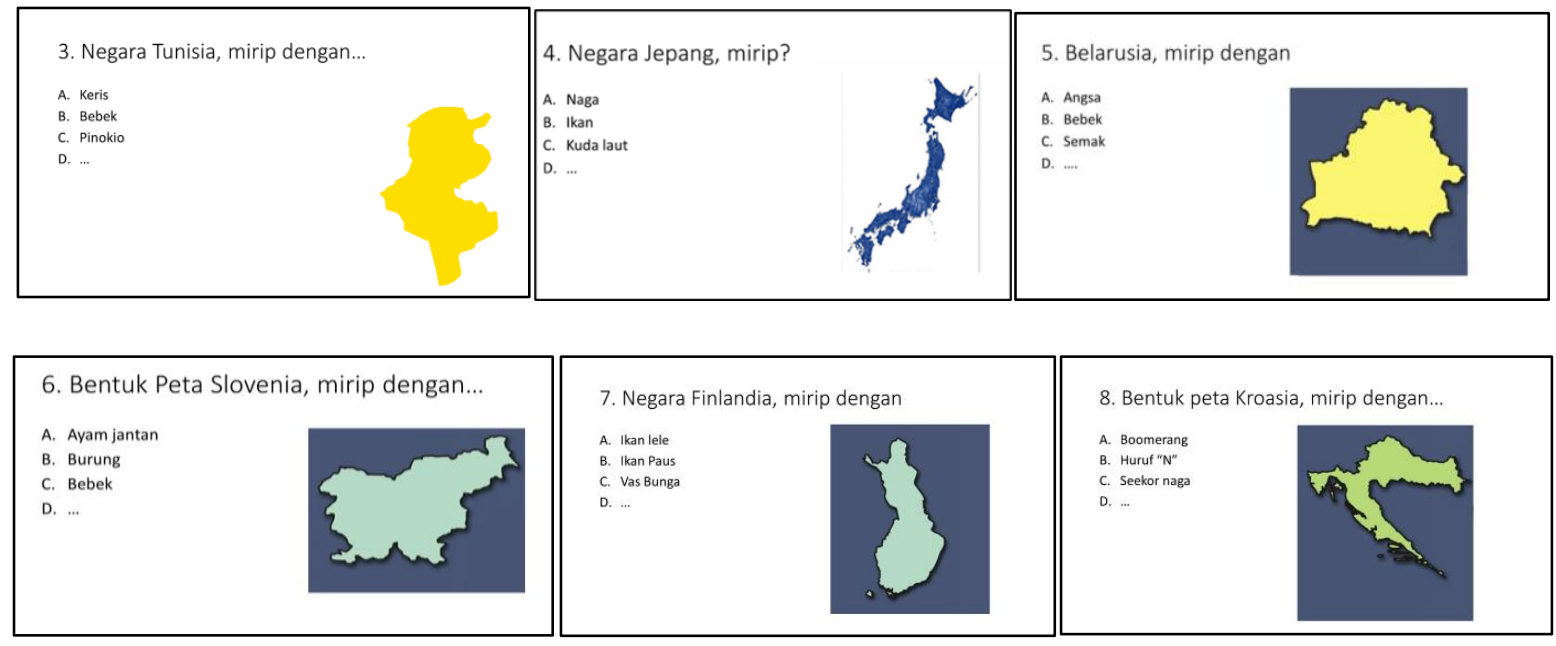

Figure 1. Research Instruments

\section{FINDINGS AND DISCUSSION}

In this study, the authors emphasize how learning methods and media help the limitations of students' abstraction power and make learning more interesting, to increase student motivation and appreciation in the learning process. The power of the media lies in resilience in memory. Humans tend to remember the most pleasant experiences, even the worst memories (Figure 2). Things that seem ordinary, rarely make an impression.

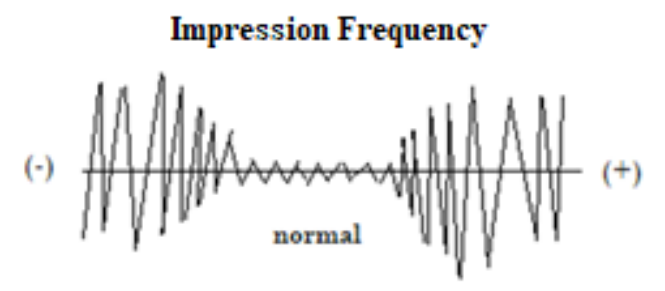

Figure 2. Impression Frequency Source: Personal documentation

This is what the writer uses to examines how the imagination map method influences the learning process, namely by providing different impressions and experiences, especially from a gender perspective.

\section{Differences in Perspective Trend}

As an opening, the author presents a map of the world as an object to be perceived, but with a bold line, and the results show that the tendency to perceive the object obtained is homogeneous. Both males and females have the same perception. $100 \%$ of respondents have the same shape perception, which is a cat (Figure 3).

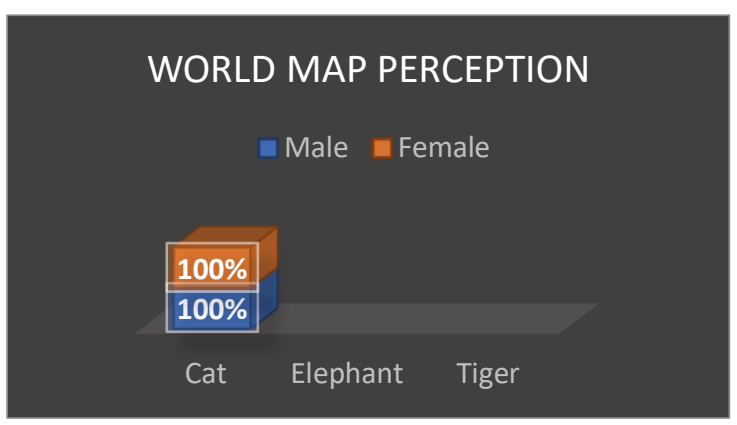

Figure 3. World Map Perception Graph

In the second question, the perception requested is a map of Italy. About $65.2 \%$ of the male respondents and $56.5 \%$ of the female respondents chose high heels as a similar object to a visual map of Italy. However, the tendency of perceptions became varies because some have different perceptions. Instead of high heels, $13 \%$ of male respondents and $17.4 \%$ of female respondents wrote completely different perceptions. They see the map of Italy as a hammer, face, stingray, keris sarong, and mermaid. And the perception of the form of rencong (Aceh's traditional weapon) is the perception chosen by a small proportion of male respondents (Figure 4). 


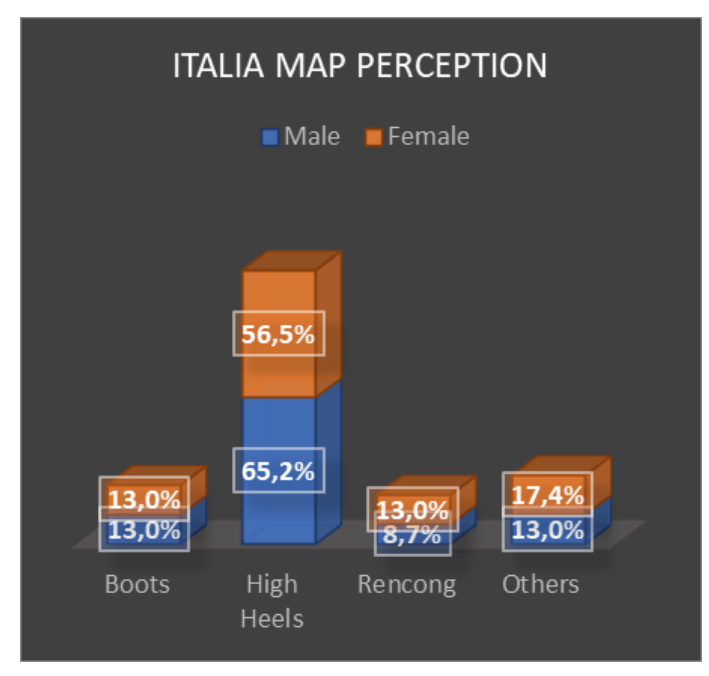

Figure 4. Perception Chart of Italy Map

This also happened to th e visual perception of the Tunisian map, where the majority of male and female respondents chose Pinocchio. Others have different imaginations, such as the shape of a bitten apple, a chimpanzee, a keris (a traditional Sundanese weapon), a sea horse, and a man with a hat.

The same thing also happened to the perception map of Croatia, the majority of respondents chose the dragon form, but the numbers have a slight difference with the respondents who chose the boomerang shape. Other perceptions shown by the students were Japanese characters, crocodile mouth gaping, dinosaur head, crocodile, and running horse.

The trend is very different between genders began to be shown in the next 3 map visuals. Firstly, the map of Japan. Although the majority chose the form of a sea horse, none of the male respondents chose the fish form. And there were no female respondents who wrote answers to different perceptions among the 3 available choices, namely dragons, fish, and sea horses (Figure 5).

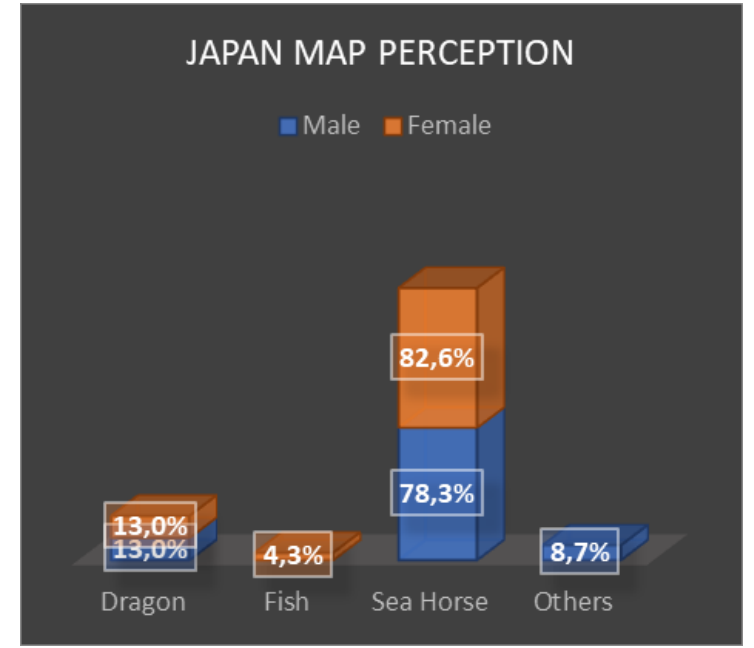

Figure 5. Perception Map of Japan

Secondly, on the Belarusian map perception, $78.3 \%$ of male respondents and $69.6 \%$ of female respondents chose the form of a bush. However, among the three choices of goose, duck, and bush, there were no male respondents who chose the duck form, while $8.7 \%$ of female respondents chose the duck form.

Lastly, on the perception map of Finland/Finnish, the majority of male respondents chose flower vases, while female respondents chose the form of catfish. There are $4.3 \%$ of female respondents who chose the form of a whale, but none of the male respondents chose this form. one male respondent even wrote that his final map was still too abstract for him, that he can't even choose any of the provided possible answers. Meanwhile, female respondents showed more creative perceptions such as hoes, statues, tadpoles, burning shields, and human hearts.

The results are uniquely shown from the perception map of Slovenia. The majority of respondents chose a rooster as the perceived form. Meanwhile, the options for birds and ducks were not selected at all (Figure 6). Other perceptions written by respondents were butterflies, hens, and dragons. 


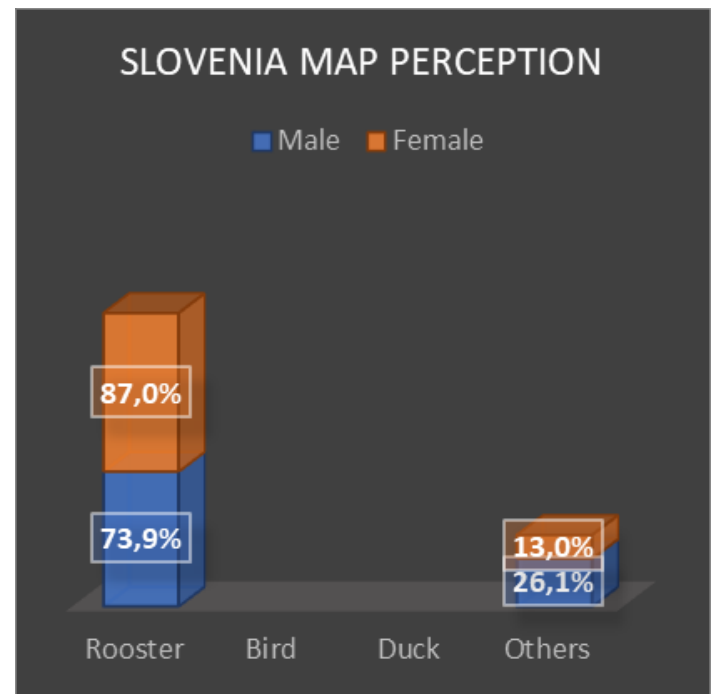

Figure 6. Perception Map of Slovenia.

Based on the above exposure results of the explanation, information can be obtained that males and females have big differences in the tendency of the results of the perception of objects. Although there will be a similar tendency for the perception of the form to be chosen nevertheless, about $40 \%$ of other students interpret the same object with different imaginations, this will certainly reduce the effectiveness of this method if it is applied in class just like that. So it should be noted that in using this method, the teacher can take advantage of the most widely selected perceptions, then present it to the class with two maps, the original map shape, and the map resulting from the interpretation which is outlined boldly. Indirectly, this could form the results of a uniform imagination for all students, loosening the rigid perceptions of males and 'limiting' the imagination of too broad objects by female students. Furthermore, it would help other students who are still having difficulty providing perceptions from an abstract object to an object that is similar to something familiar in their environment. So that differences in perceptual tendencies between genders can be minimized, and increase the effectiveness of using the imaginary map method in the classroom.

It can be concluded from the results of the analysis, the imaginary map method can be applied to encourage students to be more imaginative, and increase the likelihood that material will be stored in memory longer than relying solely on verbal explanations from the teacher.

\section{CONCLUSION}

From the research, data shows that in general, visual perceptions between male and female student respondents have the same majority tendency, the difference is that many female respondents write other broad and different perceptions. Meanwhile, the perception of male student respondents tends to be limited, because there is one respondent wrote that the visual map of Finland is still too abstract so that he can't even choose any of the provided possible answers, or finding something that similar from his neighborhood to the abstract object. Although there are choices for the majority of answers to object perception, yet about $40 \%$ of students have a completely different perception of an object. Therefore, to be applied to the classroom without being hindered by differences in gender perspectives, the teacher can work around this by providing an imaginary map with the shape of an object that has been given a bold line, so that the image is given to students can be more focused or even purpose-driven kind of attention.

\section{RECOMMENDATION}

It is necessary to examine the method of the imaginary map directly to students who currently studying map material in class, as well as the need to develop imaginary objects for maps of all countries. To further researchers to develop other learning methods in geography that involve manipulation of objects and personal experiences of students. For geography or social science subject teachers to be creative and innovative in solving learning difficulties faced by their students. 


\section{REFERENCE}

Campbell, Linda. (2004). Metode Praktis Pembelajaran Berbasis Multiple Inteligences. Intuisi Press: Depok.

Eve, R. A., Price, B., dan Counts, M. (1994). Geographic Illiteracy Among College Student. Journal Youth and Society, 25(3) 408-427. DOI: https://doi.org/10.1177\%2F0044118 X94025003006

Ginting, Cipta. (2003). Kiat Belajar di Perguruan Tinggi. PT. Gramedia Widiaswara Indonesia: Jakarta.

McLeish. (1968). The Lecture Method. Cambridge Institute of Educations.

Nazir, Moh.(2015). Metode Penelitian. PT Ghalia Indonesia: Jakarta.

Pamungkas, T, D., Ismail Arif. (2020). Best Practice Mahasiswa dalam Pembelajaran Geografi Fisik, Sosial, dan Kebencanaan di Jawa Barat (Studi Kasus: Kampung Adat Sinar Resmi dan Sekitarnya). Jurnal Geografi Gea, Volume 20, Nomor 1. DOI: https://doi.org/10.17509/gea.v 20i1.19092.g11789

Saarinen, T, F., MacCabe, C.L. (1995). World Patterns of Geographic
Literacy Based On Sketch Map Quality. Journal Professional Geographer, $\quad 47(2)$. DOI: https://doi.org/10.1111/j.00330124.1995.00196.x

Torrens, P. M. (2001). Where In The World? Exploring The Factors Driving Place Location Knowledge Among Secondary Level Student In Dublin: Ireland. Journal of Geography, 100, 49-60. DOI: https://doi.org/10.1080/00221340108 978417

Wahono, T K. (2014). Kecerdasan Visual Spasial Siswa SMP dalam Maleyelesaikan Soal Geometri Ruang ditinjau dari Perbedaan Kemampuan Matematika. Jurnal Ilmiah Pendidikan Matematika Vol. 3, No.1. ISSN: 2301-9085.

Yaumi, M dan Ibrahim, N. (2013). Pembelajaran Berbasis Kecerdasan Jamak (Multiple Intelligence) Mengidentifikasi dan Mengembangkan Multitalenta Anak. Kencana: Jakarta. 